\title{
Investigating predictors of the demand for public transport in Melbourne, Australia
}

\author{
J. F. Odgers \\ RMIT University, Melbourne, Australia
}

\begin{abstract}
The key aim of paper is to identify the most parsimonious set of independent variables that can be used to forecast the near to medium term public transport patronage levels in Melbourne, Australia. Melbourne is a capital city with a current population of 3.88 million; it is predicted grow to between 4.5 to 5 million residents by 2030 . Melbourne is served by a multi mode (train, tram and bus) and multi zone public transport system that over the last six years has seen total average annual patronage levels increase by almost $4.5 \%$ per annum. The reported patronage levels for Melbourne's train system and its tram system were collected for the 25 years 1983-84 to 2007-08. The seven independent variables used are the price of a weekly full price zone 1 ticket; the average price per litre of unleaded petrol; the lagged petrol price; the resident population of the Melbourne Statistical Division (MSD); the number of totals persons employed in the MSD; average total earnings per week; and \% of housing interest to disposable household income. Ordinary Least Squares (OLS) regression analysis is employed. The variable with the strongest correlation with annual train patronage over the whole 25 years is the average price/litre of unleaded petrol (adjusted $\mathrm{R}^{2}$ of 0.913 ). The variable with the highest correlation to tram patronage is the average unleaded fuel price lagged 6 months (adjusted $\mathrm{R}^{2}$ of 0.87). Multivariate regression analysis indicates that the addition of $\%$ of housing interest to household disposable income increases adjusted $\mathrm{R}^{2}$ for train patronage to 0.957 . Indicative forecasts of Melbourne's train patronage over the next 5 years are presented. The study's limitations are outlined.
\end{abstract}

Keywords: public transport, demand forecasting, transport planning, regression analysis. 


\section{Introduction}

This paper presents the results of a longitudinal quantitative analysis of the correlation between a range of the independent variables and the reported level of patronage of the two key elements of the public transport system in Melbourne, Victoria, Australia; namely the city's train and tram systems. It is an aggregate rather than discrete study. Its principal aim is to identify the most parsimonious set of independent variables that can be validly used to forecast the medium and the long-term patronage levels of these two modes.

The time period examined in this study is the twenty-five year period from 1983-84 to 2007-08 inclusive. This relatively long time span has enabled us to examine the strength of statistical association between a number of independent demand influencing variables and the actual or estimated numbers of Melbourne residents and /or visitors that have chosen to travel around the Melbourne region via public transport rather than by using private vehicles, without the analysis being significantly affected by the influence of short-term incidents or deviations from the longer-term pattern.

The rest of this paper comprises the following sections:

- a brief background on Melbourne and its public transport system

- a brief review of previous quantitative longitudinal studies into public transport demand influencing factors and variables;

- $\quad$ the specific research aims of this study;

- the data set and empirical methodology used in this research;

- the key results and findings of the regression analyses;

- forecasts of patronage of Melbourne's trains over the next five years; and

- overall conclusions and research limitations.

\section{Brief background of Melbourne and its public transport system}

Melbourne is the capital city of Victoria, the second most populous state in Australia. The estimated resident population of the Melbourne Statistical Division (MSD) was 3.8 million at June 2007 (Australian Bureau of Statistics [1]). Over the period 2002-03 to 2007-08 MSDs population increased on average by $1.6 \%$ per year. This growth however has not been evenly spread, with the largest and fastest growth occurring in outer fringe areas to the west, north west, north and south east of the MSD (Australian Bureau of Statistics [1]). A forecast prepared in late 2002 predicted Melbourne's population to reach 4.5 million people by the year 2031 (Eddington [2]). Subsequently this population figure has been predicted to be reached in 2020 (Birrell and Healy [3]). By 2031 Melbourne's population is now forecast to be between 4.63 and 5.11 million (Birrell and Healy [3]). The greater Metropolitan Melbourne area is very large, covering $8,829 \mathrm{~km}^{2}$, with a built-up urban area of around $2,300 \mathrm{~km}^{2}$. In comparison, the 5 boroughs of New York City (NYC) cover an area of $8005 \mathrm{~km}^{2}$ 
but NYC is home to 8.2 million people (Department of Sustainability and the Environment [4]).

Melbourne is served by three modes of public transport: rail, tram, and bus. Both the train network and the tram network operate in a radial manner, with all train spokes emanating from the CBD. Only four tram lines offer commuters north-south travel independent of a corresponding train line service. Melbourne's bus service is not included in this current study, but it does play an important role in 'filling in' the areas not serviced by either trains or trams and by offering a great deal of lateral and diagonal transit between the other two public transport modes.

Melbourne's metropolitan public transport system operates as a multi-zonal one. The zonal pricing regime started in October 1981 with the creation of three travel zones and the introduction of Travelcards that were the first tickets to offer unlimited all day travel on all metropolitan transport services across the greater Melbourne area. In March 2007, the State Government eliminated Zone 3 in an effort to reduce the cost of public transport in outer suburban areas (Minister for Public Transport [5]). There are now only two pricing zones: Zone 1 that covers the inner to middle suburbs of Melbourne, and Zone 2 that covers the outer suburban areas. A number of time based tickets can be purchased, ranging from two hours up to a yearly ticket. There are two fare levels - a full fare, and a concessional fare. Zone 1 accounted for $49 \%$ of all revenue raised in 2006-07; Zone 1 \& 2 combined equated to 34\%; and Zone $214 \%$ of total revenue in 2006-07 (Department of Transport [6]).

In the early 1950s, around 500 million boardings were made per year on Melbourne's public transport system (Department of Sustainability and Environment [7]). By 1980-81 however, total annual boardings had fallen by almost one half (Department of Sustainability and Environment [7]). Data collected for this study from published statistics on the actual (or estimated) annual boardings for Melbourne's trains and trams are presented as Figure 1. This figure shows that public transport usage over this most recent twenty five year period has increased but at an uneven rate. The late 1980s in fact saw a decline in both train and tram usage. However, since 1996-97 public transport patronage in Melbourne has been steadily growing. This increase in patronage has occurred in across all capital cities in Australia, with 19\% of adults in capital cities using public transport for trips to work or study in 2006 as compared with $16 \%$ in 2001 (Australian Bureau of Statistics [8]). Melbourne in fact showed the highest increase in public transport patronage of all Australian capital cities at a $35.1 \%$ increase (Australian Bureau of Statistics [8]). In the most recent four years (2003-04 to 2007-08) train patronage in Melbourne has grown at an average of $11.5 \%$ per year; trams at a much lower rate of $2.9 \%$ per year.

Care however must be taken when interpreting these data, for a number of reasons. One is that the annual patronage data stated are estimates rather than actual passenger boardings. A table presented by the responsible government department (Department of Infrastructure [10]) actually notes that a new measurement methodology was introduced from 2004-05. This new measurement system resulted in several changes to previously published 
patronage data. Moreover, and as noted in figure 1, a single authoritative data source on train and tram patronage in Melbourne covering the last three decades does not exist. Several separate and at times conflicting data are presented by public authorities. Indeed, the estimated train and tram boardings data gathered for this research for the years 1980-81 to 1988-89 resulted in three separate figures for total annual boardings based on three different governmental information sources. A third reason for caution is that from 29 August 1999 the operation of Melbourne's public transport has been in the hands of private operators, when the franchise contracts were signed between the winning bidders and the State Government in 1999were signed. An unfortunate consequence of this government decision for researchers has been the loss of direct access to comprehensive public transport historical data sets, especially for time periods earlier than 1995. This makes it more difficult to undertake longitudinal quantitative studies of transport demand and its components and contexts.

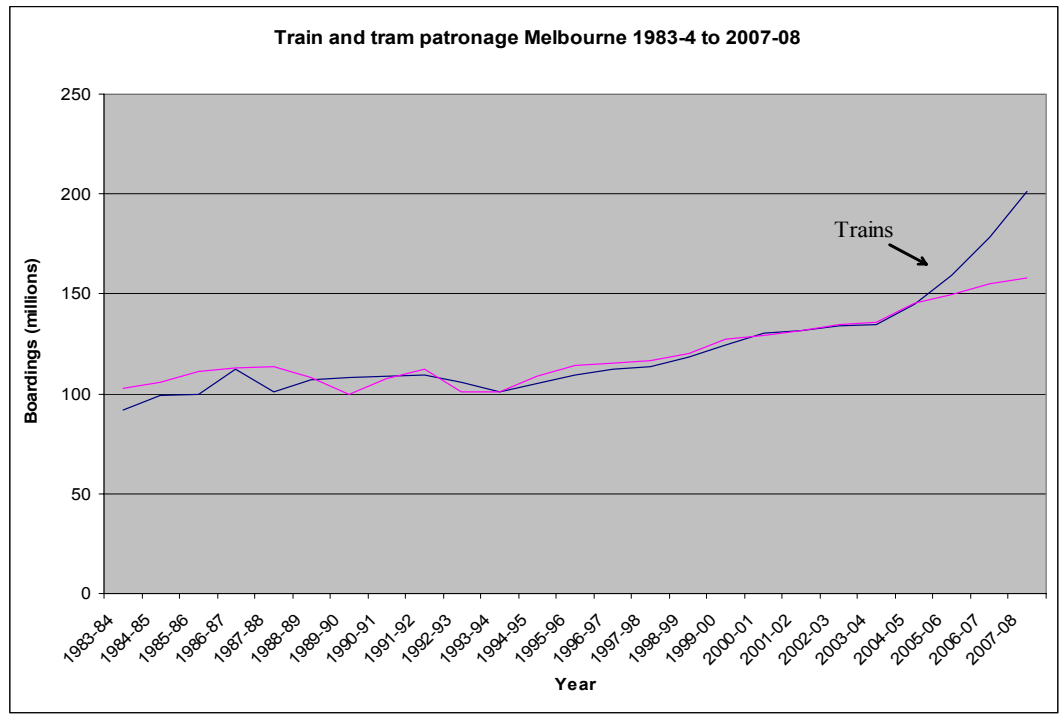

Figure 1: Melbourne's public transport patronage 1983-4 to 2007-08. Sources: Australian Bureau of Statistics [9]; Victorian Auditor General [10]; Minister for Transport [11].

\section{Review of previous quantitative studies of variables associated with transit demand}

Independent variables used by earlier quantitative research studies are either of an external or an internal type. External type variables are those largely exogenous to the public transport system and its managers - such as employment levels and employment density, service area population, private vehicle access and/ or ownership, income levels, price of gasoline, and the cost 
of vehicle parking'. The internal type of variables includes such factors as fares and service levels (Taylor and Fink [14]). Taylor et al. [15] find that the most significant factors influencing transit use are external to transit systems. However among the internal factors, increasing the quantity of service (in terms of service coverage and service frequency) and reducing fares 'are both found to have significant effects on ridership' (Taylor et al. [15].

More specifically several studies have reported quantitative results that are relevant to the current study. Taylor et al. [15] include among their quantitative findings these specific $\mathrm{R}^{2}$ statistics:

- Overall transit ridership tracked both of these measures closely -0.79 with the real GDP, and 0.82 with the real GDP per capita.;

- The correlation coefficient between the number of unlinked trips and Real Average Fare (2001) is -0.61 .

- The correlation between average real wages and total transit ridership during the 1990s was almost perfect (0.96)

Hendrickson [16] as cited in Taylor et al. [15] in a cross sectional study of 25 large U.S. cities reports a regression model using four variables - percentage of workforce in CBD, absolute number of workers in $\mathrm{CBD}$, absolute number of work transit trips, percentage of work trips taken on transit. Hendrickson [16] finds that $\mathrm{CBD}$ employment numbers explained 96 percent of the variation of public transit use. Chen [17] reports on a longitudinal study of train demand in London over the years 1995 to 2002. Of the variables investigated, central London employment is the most important factor that affects transport demand (Chen [17]). Balcombe et al. [18] also notes that in the U.K. demand rail travel 'appears to be strongly correlated with employment (Balcombe [18]).'

Morral and Bolger [19] as cited in Taylor and Fink [14] present a very different result. They found that the number of downtown parking stalls per CBD employee explained 92 per cent of the variation in percent transit modal split for Canadian cities and 59 percent for Canadian and American cities combined. Chung [20] also finds that parking is the most significant factor affecting transit ridership.

Kohn [21] examines data from 1992 to 1998 in a study of 85 Canadian urban transit agencies. Together, average fare and revenue vehicle hours explained $97 \%$ of changes in urban transport demand.

While not seeking to identify multiple variables associated with changes in public transport demand, the statistical analysis by Currie and Phung [22] of the relationship between fuel price changes and public transport demand in Melbourne Australia is informative. Specifically Currie and Phung [22] find that cross elasticities in general are highest with a 7-month time lag for rail has influenced the choice of independent variable used in the current study.

To close this brief review, three points raised by Taylor and Fink [14] in their critique of the causal models on public transport patronage reviewed by them seem apposite.

1. There are persistent problems of multicollinearity between the independent variables in the same models.

2. Some probably important factors are hard to quantify into variables. 
3. All of the studies suffer from loss of disaggregate analysis: fully understanding the determinants of transit mode choice 'requires that analyses be disaggregated to the household or even trip level. But such analyses are extraordinarily data intensive and expensive to conduct.

\section{Specific research aims}

The primary aims of this research are:

1. to investigate the degree of statistical association between the historical levels of demand (as measured by millions of boardings per year) for the two of the three modes of public transport in Melbourne and a small number of range of independent external variables over the last twenty five years;

2. to identify the most parsimonious set of external variables that are most closely correlated with the annual movements in transport patronage for train and tram commutes in Melbourne over the period 1983-84 to 2007-08; and

3. to use the resultant regression equations for present forecasts of train and tram demand over the next 5 and 10 year periods.

\section{Model and empirical methodology}

The variables chosen for use in this research are informed by the earlier research reviewed in section 3, along with the current researcher's own judgements about potentially relevant external variables. The resultant model used in this paper can be expressed in its most generic form as:

where

$$
D_{T}=f\left(T_{W}, U_{P}, P E_{M}, E_{W}, P_{M} I_{Y}, \varepsilon\right)
$$

$D_{T} \quad$ is the actual or estimated millions of boardings per year on either trams or trains

$T_{W} \quad$ is the price of a full fare Zone 1weekly ticket

$U_{P} \quad$ is the average annual price per litre of unleaded petrol in Melbourne

$P E_{M}$ is the estimated number of persons employed (both full and part time) in the Melbourne Statistical Division

$E_{W} \quad$ is the total weekly earnings of persons (in Victoria)

$P_{M} \quad$ is the estimated resident population in the Melbourne Statistical Division

$I_{Y} \quad$ is the percentage of household interest payments for housing to household disposable income.

$\varepsilon \quad$ a stochastic disturbance term that captures the influence of other unquantifiable and/or unidentifiable factors on the demand.

Inclusion of the last variable $I_{Y}$ is based on the proposition that decisions on which mode of personal transport to use are made partly on the basis of the total amount of household income that is available after the payment of the household mortgage. The higher the percentage of disposable household income consumed by this long-term financial commitment, the greater is the likelihood we argue that public transport will be chosen ahead of private motor vehicle transport. 
Annual data for each of these independent variables was collected on each of these variables for the fiscal years ending June 301984 to June 30 2008. Table 1 summarises the primary specific data sources for each variable

Table 1: Data sources for independent variables.

\begin{tabular}{|l|l|}
\hline \multicolumn{1}{|c|}{ Variable } & Primary data source(s) \\
\hline Price of Zone 1 full fare ticket & Minister for Public Transport \\
& {$[23]$} \\
\hline $\begin{array}{l}\text { Average annual price/ litre of } \\
\text { unleaded petrol, Melbourne }\end{array}$ & Australian Bureau of Statistics \\
{$[24]$} \\
\hline $\begin{array}{l}\text { Average annual price/litre of } \\
\text { unleaded petrol in Melbourne, } \\
\text { lagged 6 months }\end{array}$ & $\begin{array}{l}\text { Australian Bureau of Statistics } \\
{[24]}\end{array}$ \\
\hline Total persons employed, MSD & Australian Bureau of Statistics \\
& {$[25]$} \\
\hline $\begin{array}{l}\text { Total weekly earnings, persons } \\
\text { employed }\end{array}$ & Australian Bureau of Statistics \\
\hline $\begin{array}{l}\text { Estimated rresident population in } \\
\text { the MSD }\end{array}$ & $\begin{array}{l}\text { Australian Bureau of Statistics } \\
{[27]}\end{array}$ \\
\hline $\begin{array}{l}\text { Percentage of housing interest } \\
\text { payments to household income }\end{array}$ & Reserve Bank Australia [28] \\
\hline
\end{tabular}

The resultant data set was analysed using Ordinary least Squares regression analysis facilitated by the SPSS software. Univariate linear regression analysis was performed using each of the seven independent variables for both of the dependent variables - annual train patronage and annual tram patronage - over the years $1983-84$ to $2007-08$. The resultant equations were examined especially in respect of the $\mathrm{R}^{2}$, adjusted $\mathrm{R}^{2}$, Standard Error of Estimate (SEE), and $t$ value. The second analytical method used was a hierarchical regression analysis. All calculations were performed at the $5 \%$ level of significance.

\section{Results and discussion}

Table 2 presents selected results of univariate OLS regression analysis for both dependent variables and the seven independent variables studied. All reported results are at the 5\% level of significance. As indicated in Table 2, the three most explanatory independent variables affecting train demand are in rank order the average price of unleaded petrol $\left(\mathrm{X}_{6}\right)$, and \% interest paid to household income $\left(\mathrm{X}_{7}\right)$ and resident population $\left(\mathrm{X}_{5}\right)$ For trams the three most explanatory variables are the lagged average price of unleaded petrol $\left(\mathrm{X}_{2}\right)$, total persons employed $\left(\mathrm{X}_{3}\right)$ and resident population $\left(\mathrm{X}_{5}\right)$.

The single most notable finding of this analysis is that the correlation between the average annual price per litre of unleaded petrol and both train and tram patronage in Melbourne during the period 1983-84 to 2007-08 is very high. As 
noted in Table 2, the adjusted $\mathrm{R}^{2}$ for train boardings is 0.913 ( $\mathrm{SEE}=7.717$; $\mathrm{t}$ value $=5.876$ ). The strength of correlation between average annual fuel price and tram patronage is lower $\left(\right.$ adjusted $\mathrm{R}^{2} 0.834$; $(\mathrm{SEE}=7.100 ; \mathrm{t}$ value $=$ 11.036).). However, the related variable lagged unleaded petrol price yielded the highest adjusted $\mathrm{R}^{2}$ for tram boardings of $0.871(\mathrm{SEE}=7.1$; $\mathrm{t}$ value $=11.034)$. Univariate regression analysis shows that the observed strength of association between the average annual unleaded petrol price and the two dependent variables in fact has slightly increased over the most recent decade (1998-99 to 2007-08) These results on the direct association between fuel price and transit demand support those of Sale [29], but contradict the results reported by McLeod et al. [30].

Table 2: $\quad$ Univariate regression results.

\begin{tabular}{|c|c|c|c|c|c|c|}
\hline Variable & \multicolumn{3}{|c|}{ Trains } & \multicolumn{3}{c|}{ Trams } \\
\cline { 2 - 7 } & Adj. $\mathrm{R}^{2}$ & SEE & t value & Adj. $\mathrm{R}^{2}$ & SEE & t value \\
\hline $\mathrm{X}_{1}$ & 0.721 & 13.812 & 7.929 & 0.770 & 8.354 & 9.031 \\
\hline $\mathrm{X}_{2}$ & 0.902 & 8.172 & 14.909 & 0.871 & 6.281 & 12.728 \\
\hline $\mathrm{X}_{3}$ & 0.789 & 12.000 & 9.527 & 0.861 & 6.501 & 12.236 \\
\hline $\mathrm{X}_{4}$ & 0.772 & 12.485 & 9.060 & 0.805 & 7.692 & 10.017 \\
\hline $\mathrm{X}_{5}$ & 0.803 & 11.605 & 9.931 & 0.831 & 7.154 & 10.937 \\
\hline $\mathrm{X}_{6}$ & 0.913 & 7.718 & 15.876 & 0.834 & 7.100 & 11.034 \\
\hline $\mathrm{X}_{7}$ & 0.890 & 8.649 & 13.999 & 0.293 & 24.901 & 3.308 \\
\hline
\end{tabular}

Another very interesting result of this study is the unexpected nature of relationship between weekly zone 1 fare and both tram and train patronage. Specifically for the years 1983-84 to 2007-08 inclusive, the average price elasticity in Melbourne, Australia, for trains is 0.79 and for trams 0.64 . Both these data are substantially different from the price elasticities reported in a large number of earlier research studies. For example, the average own price elasticity for rail calculated from nineteen studies reported by the Bureau of Transport Economics [31] is -0.43 to -0.75 . Beko [32] presents point elasticity estimates of price elasticity for rail travel in Slovenia ranging from -0.203 to -0.401 . Balcombe et al. [18] reports local suburban rail fare elasticity of -0.06 in the short run. One possible explanation for both the counter-intuitive direction of the association between price and quantity demanded in the current study is that the average price of a full weekly ticket in Melbourne as a percentage of average weekly earnings has remained at about $3.1 \%$, with a standard deviation of only 0.17, over the years 1989-90 to 2007-08. Public transport fares then have been a consistently and relatively low percentage of average weekly earnings.

Multivariate analysis was also performed. A summary of the three statistically strongest results for both dependent variables are shown in Table 3 .

One key finding of the multivariate analysis is that the addition of variable $\mathrm{X}_{7}$ (\% housing interest paid to household disposable income) to variable $\mathrm{X}_{6}$ (average price / litre of unleaded petrol) has a positive effect on the explanatory 
power of the resultant causal model, in that adjusted $\mathrm{R}^{2}$ increases to 0.959 and SEE falls from 7.718 to 5.314. The second key finding from the multivariate analysis is that the strength of association between the specific independent variables used in this research and the demand for Melbourne's train services is greater than that for its tram services. One would thus be more confident of the predictive power of forecast patronage levels using these variables for train patronage as compared to tram patronage. Our analysis now turns to this forecasting process.

Table 3: $\quad$ Multivariate analysis results.

\begin{tabular}{|l|c|c|l|c|c|c|}
\hline \multirow{2}{*}{ Variables } & \multicolumn{3}{|c|}{ Trains } & \multicolumn{3}{c|}{ Trams } \\
\cline { 2 - 7 } & $\begin{array}{c}\text { Adj. } \\
\mathrm{R}^{2}\end{array}$ & SEE & $\mathrm{t}$ values & $\begin{array}{c}\text { Adj. } \\
\mathrm{R}^{2}\end{array}$ & SEE & $\mathrm{t}$ values \\
\hline $\mathrm{X}_{6}, \mathrm{X}_{7}$ & 0.959 & 5.314 & $6.109,5.15$ & & & \\
\hline $\mathrm{X}_{6}, \mathrm{X}_{7}, \mathrm{X}_{3}$ & 0.955 & 5.535 & $\begin{array}{l}4.405,4.743, \\
0.106\end{array}$ & & & \\
\hline $\mathrm{X}_{6}, \mathrm{X}_{7}, \mathrm{X}_{5}$ & 0.952 & 5.670 & $\begin{array}{l}3.661,4.714, \\
-0.053\end{array}$ & & & \\
\hline $\mathrm{X}_{2} \mathrm{X}_{3}$ & & & & 0.888 & 5.829 & $2569,2.167$ \\
\hline $\mathrm{X}_{6}, \mathrm{X}_{3}$ & & & & 0.884 & 5.929 & $3.314,2.377$ \\
\hline $\mathrm{X}_{3}, \mathrm{X}_{4}, \mathrm{X}_{6}$ & & & & 0.883 & 5.96 & $\begin{array}{l}2.856,-0.877, \\
2.493\end{array}$ \\
\hline
\end{tabular}

\section{Forecasts of train patronage}

The forecast of train patronage (T) presented at Table 4 is based on the following equation drawn from the results of multivariate analysis outlined immediately above (all cases $a=0.05$ ).

$$
T=39.6+59.5348 X_{6}+6.4427 X_{7}+5.314
$$

where $\mathrm{T}=$ Forecast train boardings;

$\mathrm{X}_{6}=$ forecast price/ litre unleaded petrol;

$\mathrm{X}_{7}=$ forecast $\%$ of housing interest paid to household disposable income.

The last forecast presented in Table 4 is based on the multivariate regression analysis of the most recent five years, since the correlation between train boardings and independent variable 7 has strengthened considerably over this most recent term (Adjusted $\mathrm{R}^{2}$ 0.985; SEE 3.292; t statistic 16.05).

These forecasts are presented with considerable caution, for two main reasons. The first is that short-term oil price forecasting has been challenging in recent times, and since 2004, 'a large number of oil price forecasters, including ABARE, have consistently underestimated the increase in world oil prices' (Copeland and Kendall [33]). The second cause for concern is the unknown future impacts of very recent and very substantial drops in official interest rates in Australia both on the dollar value of household interest payments for housing finance and on household disposable income levels. Given the volatility of these 
two external variables no attempt has been made to forecast train boardings for the next ten years.

Table 4: $\quad$ Forecast of train boardings (millions) 2008-9 to 2012-13.

\begin{tabular}{|c|c|c|c|c|c|}
\hline & \multicolumn{4}{|c|}{ Forecast based on most recent 25 years } & $\begin{array}{l}\text { Forecast } \\
\text { based on most } \\
\text { recent } 5 \text { years }\end{array}$ \\
\hline Year & $\begin{array}{l}\text { Forecast : } \\
\text { Base case } \\
\text { (1) }(2)\end{array}$ & $\begin{array}{l}\text { Lowest case } \\
\text { forecast }\end{array}$ & $\begin{array}{l}\text { Highest case } \\
\text { forecast }\end{array}$ & $\begin{array}{l}\text { Expected } \\
\text { value } \\
\text { forecast }^{(2)}\end{array}$ & \begin{tabular}{|l|} 
Expected \\
value \\
forecast $^{(2)}$ \\
\end{tabular} \\
\hline 2008-09 & 193.0 & 188.5 & 208.7 & 194.7 & 194.4 \\
\hline $2009-10$ & 188.9 & 180.3 & 214.0 & 191.4 & 185.9 \\
\hline $2010-11$ & 184.8 & 166.5 & 222.0 & 187.9 & 176.3 \\
\hline 2011-12 & 179.4 & 165.9 & 227.6 & 184.6 & 167.1 \\
\hline $2012-13$ & 174.7 & 165.1 & 236.4 & 182.5 & 162.3 \\
\hline
\end{tabular}

Notes:

(1) Assumes ULP price/ litre will revert to long-term trend over next 5 years and housing interest to disposable household income will revert to l-t trend over next 4 years, based on observable pattern over most recent 25 years of data.

(2) Most likely case $p=0.7$ : lowest case and highest case: $p=0.15$

\section{Overall conclusions and study limitations}

The only two independent variables that yielded an adjusted $\mathrm{R}^{2}$ of 0.9 or more are used to forecast demand for Melbourne's trains over the next five years. The resultant forecast predicts a reduction in demand. The two variables that most directly are associated with tram demand are not the same as those for train demand; and their adjusted $\mathrm{R}^{2}$ are less than 0.9.

The limitations of this study include those alluded to earlier in this paper. Proposed future research seeks to redress these limitations, provided that the necessary data are available and reliable.

\section{References}

[1] Australian Bureau of Statistics, Regional Population Growth 1100.2 Statistics Victoria, March 2008

[2] Eddington, R., Overview: East West Link Need Assessment, Report to the Premier of Victoria, Melbourne, Victoria, AU. March 2008

[3] Birrell, B. and Healy, E., Melbourne's population surge, CPUR Bulletin, Monash University, Centre for Population and Urban Research, Melbourne, pp. 1-9, 2008.

[4] Department of Sustainability and the Environment, Melbourne at a Glance, Victorian Government, Melbourne, 2004 
[5] Minister for Public Transport, Removal of Zone 3 coming soon, Media Release, Government of Victoria, Melbourne, February 22, 2007

[6] Department of Transport, Expression of Interest Brief Appendix $A+B$ Melbourne Metropolitan Tram (MR3 014) and Train (MR3 015) Franchises Victorian Government, Melbourne, 2008.

[7] Department of Sustainability and the Environment, Melbourne Atlas 2006 Living in Melbourne, Victorian Government, Melbourne, 2006.

[8] Australian Bureau of Statistics, Australian Social Trends, Catalogue Number 4102.0, Canberra, ACT, 2008.

[9] Australian Bureau of Statistics, Victoria Year Book, Melbourne, 1989.

[10] Victorian Auditor General, Report on Ministerial Portfolios, Melbourne, 1995.

[11] Minister for Transport Press Release, Metropolitan Melbourne Public Transport Patronage Historical Time Series - Excluding Commonwealth Games, Melbourne, Table 18, December 72007

[12] Premier of Victoria, Passenger numbers continue to grow on Melbourne's Public Transport Network Press Release, Victorian Government, Melbourne, 20 August 2008.

[13] Department of Infrastructure Annual Report 2006/07, Melbourne, Victorian Government

[14] Taylor, B. D. and Fink, C. N. Y. (nd):, The Factors Influencing Transit Ridership: A Review and Analysis of Transit Ridership Literature, Working Paper, UCLA Department of Urban Planning, Los Angeles, CA, UCLA Institute of Transport Studies.

[15] Taylor, B. D, Hass, P. and Boyd, B. et al., Increasing transit Ridership: Lessons From the Most Successful Transit Systems in the 1990s MTI Report 01-22, San Jose University, San Jose 2002.

[16] Hendrickson, C., A Note on the Trends in Transit Commuting in the U.S. Relating to Employment in the CBD, Transportation Research, Part A: General 20A(1): 33-37 1986.

[17] Chen, N., Modelling Demand for Rail Transport with Dynamic Econometric Approaches, International Review of Business Research Papers, Vol. No. 3, Issue 2 July, 2007, pp. 85-96.

[18] Balcombe, R. (ed) et al., The demand for public transport: A practical guide, TRL Report TRL593, TRL Limited, London, 2004.

[19] Morral, J. and Bolger, D., The Relationship Between Downtown Parking Supply and transit Use, ITE Journal, 66(2), pp. 32-36, 1996.

[20] Chung, K., Estimating the Effects of Employment, Development Level, and Parking Availability on CTA Rapid Transit Ridership: From 1976 to 1995 in Chicago', Metropolitan Conference on Public Transportation Research: 1997 Proceedings, May 30, University of Illinois, Chicago, pp. 255-64, 1997.

[21] Kohn, H., Factors Affecting Urban Transit Ridership, Bridging the Gaps Conference, Canadian Transportation Research forum, Charlottetown, Prince Edward Island, Canada, June 6, 2000. 
[22] Currie, G. and Phung, J., Exploring the Impacts of Fuel Price Increases on Public Transport use in Melbourne', $29^{\text {th }}$ Australasian Transport Research Forum. 2006

[23] Minister for Public Transport, Various Press Releases over years 1999 2008.

[24] Australian Bureau of Statistics, Average Retail Prices of Selected Items (Cat 6403.0), Canberra ACT, 2008.

[25] Australian Bureau of Statistics, Labour Force Regions June Quarter 2007 Not Seasonally Adjusted Canberra, ACT, 2007.

[26] Australian Bureau of Statistics, Australian Economic Indicators July, Canberra ACT, Table 6 Table 7.4, 2008.

[27] Australian Bureau of Statistics, (i) Victorian Year Book, 1989 Canberra, ACT; (ii) National Regional Profile Canberra, 2008.

[28] Reserve Bank of Australia, Household Finances: Selected Ratios, Canberra ACT, Table B21, 2008.

[29] Sale, J., Increasing Transit Ridership: The Experience of Seven Cities U.S. Department of Transportation, November, 1976.

[30] McLeod, M.S, Flannelly, K., Flannelly, L. and Behnke, R., Multivariate Time-Series Based Model of Transit Ridership Based on Historical Aggregate Data: The Past, Present and Future of Honolulu', Transportation Research Record No. 1297, pp. 76-84, 1991

[31] Bureau of Transport Economics: Summary of Rail Elasticities from Studies in BTRE Database, Canberra, ACT, Table 3, 2002.

[32] Beko, J., Demand Functions for Service of Public Railway Passenger Transportation: An Empirical Analysis for Slovenia, Managing Global Transitions, 1(2) pp. $135-152,2003$.

[33] Copeland, A. and Kendall, R., Oil and Gas, ABARE 2008 Australian Commodities June Quarter 08.2, Canberra, ACT 2008. 